\title{
ANALISIS FAKTOR-FAKTOR YANG MEMPENGARUHI MINAT NASABAH MENGGUNAKAN $M$-BANKINGBERDASARKAN TEORI TAM
}

\author{
CHRISTINE CLARA CAROLINE * \\ THERESIA DWI HASTUTI \\ Magister Akuntansi \\ Universitas Katolik Soegijapranata \\ *christine.clara027@gmail.com
}

\begin{abstract}
This study aims to determine the positive influence of Perceived Ease of Use (PEOU), Perceived Ease of Use (PEOU), Perceived Usefulness (PU), Subjective Norm (SN), Subjective Norm (SN) on Intention to Use (ITU), and To determine the positive effect of Attitude (A) on Intention to Use (ITU). The sample is 207 respondents using M-Banking in Yogyakarta. SEM AMOS is used and has an effect on attitudes (A) of M-Banking users, Subjective Norms (NS) have a positive effect on interest in using (ITU) M-Banking, Perceived ease of use (PEOU) has a positive effect on perceived benefits (PU). M-Banking, Perceived Benefit (PU) has a positive effect on Interest in Using (ITU) M-Banking, Subjective Norms (SN) has a positive effect on Perceived Benefit (PU) M-Banking, Subjective Norms (NS) there is a relationship with interest (ITU) ) M-Banking, Attitude (A) there is a relationship in (ITU) M-Banking.
\end{abstract}

Keywords: Perceived ease of use (PEOU), perceived benefit (PU), attitudes (A), Subjective Norms (NS), interest in using (ITU), M-Banking

\begin{abstract}
Abstrak: Penelitian ini bertujuan untuk mengetahui pengaruh positif Perceived Ease of Use (PEOU), Perceived Ease of Use (PEOU), Perceived Usefulness (PU), Subjective Norm (SN), Subjective Norm (SN) terhadap Intention to Use (ITU), dan Untuk mengetahui pengaruh positif Attitude (A) terhadap Intention to Use (ITU).Sampel berjumlah 207 responden pengguna M-Banking di Yogyakarta. SEM AMOS yang digunakan dan berpengaruh pada sikap (A) pengguna M-Banking, Subjective Norms (NS) berpengaruh positif terhadap minat menggunakan (ITU) M-Banking, Persepsi kemudahan penggunaan (PEOU) memiliki efek positif pada manfaat yang dirasakan (PU). M-Banking, Perceived Benefit (PU) berpengaruh positif terhadap Minat Menggunakan (ITU) M-Banking, Subjective Norms (SN) berpengaruh positif terhadap Perceived Benefit (PU) M-Banking, Subjective Norms (NS) adanya sebuah hubungan pada minat (ITU) M-Banking, Sikap (A) adanya sebuah hubuangan pada (ITU) M-Banking.
\end{abstract}

Kata kunci. Perceived ease of use (PEOU), perceived benefit (PU), sikap (A), Subjective Norms (NS), interest in using (ITU), M-Banking

\section{PENDAHULUAN}

Teknologi digital yang semakin maju, memberikan dampak bagi perbankan dalam mengembangkan sistem digitalnya untuk memudahkan nasabah dalam melakukan transaksi. Berdasarkan data diketahui bahwa saat ini jumlah bank komersial sudah berkurang yang sebelumnya berjumlah 120 bank pada tahun 2014 kini menjadi 111 bank pada tahun 2019. Begitupula dengan perkembangan kantor cabang yang menurun hingga 1.552 dari tahun 2015-2019.

Betani (2014), Khaled et al (2013), dan Rizky (2015) pada penelitiannya menemukan sebuah fenomena dimana terdapat sebuah faktor yang berhubungan pada tingginya CAR pada bank. Selain itu berkembangnya fintech dengan persyaratan yang lebih mudah juga dapat menarik minat masyarakat dalam menggunakannya. Jika dibandingkan dengan persyaratan M-Banking, naasabah lebih dahulu perlu membuat rekening lalu barulah bisa nasabah menggunakan M-Banking sedangkan untuk 
penggunaan fintech sendiri jauhg lebih mudah dan sederhana. Pengguna cukup melakukan registrasi sederhana pada aplikasi fintech, lalu pengguna dapat menggunakan untuk berbagai transaksi.

Mobile banking adalah kategori media sosial yang menarik untuk Mesin Konteks atau rekomendasi sistem karena jumlah aplikasi praktis. Sumber menarik informasi mungkin foursquare, twitter, Linkedln dan Wikipedia. Khususnya, platform media sosial terbuka, yang menawarkan konten terbuka tanpa otentikasi, adalah dari minat tertentu, beberapa contohnya adalah twitter, Flickr atau YouTube. Meskipun media sosial adalah sumber informasi yang kaya, ada dua masalah yang menghambat perkembangannya yang intinya sama dengan informasi virtual tetapi lebih ditekankan: Pertama, kebutuhan untuk mengatasi informasi dalam format yang tidak dapat dibaca oleh mesin, seperti plaintext, yang mana teknik penambangan data dan teks tingkat lanjut harus dikembangkan lebih lanjut. Kedua, kedekatan atau ketidaktersediaan data penting: penyedia layanan mungkin memilih untuk tidak mengungkapkan informasi tersebut, seringkali penting dalam model bisnis. Menurut Fadlan (2018) Mbanking dapat mempengaruhi sebuah perkembangan dengan sistem yang disajiakn sangat mudah dengan melibatkan pihak bank dan nasabah bank.

Pelanggan telah mendapatkan banyak manfaat, nyatanya layanan ini jarang digunakan oleh pelanggan dan seringkali tidak menarik. Nasabah lebih memilih melakukan transaksi melalui ATM atau mengantri di bank. Faktanya, pengguna mobile banking di Indonesia lebih sedikit dibandingkan pengguna internet. Indonesia memiliki 25 juta pengguna internet dan populasi 272,1 juta (Detik.com, 2020), sedangkan aplikasi mobile banking Bank Mandiri memiliki sekitar 5 juta pengguna. Banyak pelanggan memiliki layanan mobile banking tetapi tidak pernah menggunakannya karena pengoperasian sistem terkadang tampak rumit, dan tidak semua orang mengerti cara menggunakannya. Dampak lainya yang akan diakibatkan yaitu dengan peningkatan nasabah yang terbatas dalam menggunakan smartphone, akan membawa sebuah faktor yang negatif karena pelanggan belum terbiasa dengan digital.

Sistem informasi yang memberikan sebuah kemudahan dalam menjalankan sebuah teknologi disebut dengan TAM. TAM memiliki manfaat memberikan sebuah hubungan dengan para pengguna teknologi dalam sebuah variasi yang sangat luas bagi penggunanya. Komponen ini berkaitan erat dengan kemudahan dan kegunaan. Dua aspek ini saling berkaitan dengan Theory of Planned Behavior (TPB), yang menjelaskan bahwa pengaruh sebuah minta dengan perilaku pada sebuah struktur pada kontrol perilaku (Fadlan, 2018).

Berdasarkan penelitian dari Enrico (2019) dengan menggunakan 5 (lima) faktor yang mempengaruhi minat menggunakan emoney yaitu perceived usefulness (PU), perceived ease of use (PEOU), risiko, kepercayaan dan gender. Teori Davis menjelaskan bahwa persepsi kemudahan dan kegunaan merupakan faktor yang tepat dalma meningkatkan sebuah teori yang mempengaruhi keinginan pada penggunaan M-banking.

Salah satu model yang banyak digunakan adalah teori aksi beralasan (Theory of Reason Action - TRA). Ajzen (1975) menjelaskan bahwa perilaku sadra seorang individu dalam sebuah framework memberikan sebuah hasil yang kognitif. Sedangkan TPB adalah perluasan dari TRA (Ajzen \& Fishbein, 1980). Seperti halnya TRA faktor sentral di dalam teori ini alah intensi/ maksud untuk melakukan suatu perilaku. Semakin kuat intensi yang dimiliki maka semakin besar kemungkinan seseorang untuk melakukan perilaku tersebut (Ajzen, 1991).

Dalam penelitian ini, peneliti menggukan teori TAM dan TPB yang berbeda dengan penelitian sebelumnya menggunakan teori TAM dan TRA, dan menambahkan variabel Subjective Norm (SN) dan Perceived Behavioral Control (PBC) untuk sampel yang digunakan berbeda dari penelitian sebelumnya, dalam penelitian ini dilakukan di Yogyakarta.

TPB memiliki faktor pembentuk yaitu PBC dan NS, sedangkan TAM faktornya adalah PEOU, PU dan Attitude. Penjelasan PBC ke PEOU adalah semakin tinggi PBC mengindikasikan bahwa semakin 
baik kontrol perilaku seseorang sehingga akan meningkatkan kemudahan penggunaan. Semakin baik kontrol perilaku (PCB) mengindikaskan seseorang dalam menggunakan M-Banking dapat dikontrol lebih baik, sehingga akan meningkatkan persepsi kemudahan penggunaan M-Banking. Dengan demikian dapat dikatakan bahwa Persepsi kontrol perilaku (PBC) berpengaruh positif terhadap persepsi kemudahan penggunaan (PEOU) M-Banking (Ajzen, 1991).

\section{Theory of Planned Behavior(TPB)}

Ajzen (1991) dalam penjelasanya TPB merupakan sebuah teori yang menjelaskan sebuah perilaku kontrol yang nantinya akan mempengaruhi perilaku serta minta pada nasabah dalam menggunakan sebuah teknologi. Terdapat 3 aspek pada TPB 1) sebuah penilaian yang memiliki jawaban setuju atau tidak setuju pada cerminan yang dimiliki individu 2) perilaku yang dihasilkan pada sebuah tekanan sosial 3) kemudahan dan kesulitan dalam mengontrol sebuah perilaku.

\section{Model Penerimaan Teknologi (TAM)}

Model TAM atau technology acceptance model dikembangkan oleh Davis F.D (1989), dan menjelaskan tentang sebuah pemakai teknologi yang dimudahkan dalam menggunakannya. Adopsi teori ini mengenai sebuah faktor yang digunakan dalam memberikan sebuah analisis dalem penggunaan teknologi baru pada pengguna teknologi yang telah digunakan. Dokumen hasil dari sebuah teknologi yang digunakan biasnya berupa teori penalaran yang terdiri dari Action (TRA) dan Planned Behavior Theory (TPB).

\section{Teori Tindakan Rasional (TRA)}

Teori ini dikemukakan oleh Fishbein \& Ajzen (1975) Asumsi dasar yang digunakan dalam strukturnya adalah bahwa manusia adalah makhluk yang memiliki kekuatan rasional dan secara sadar dapat memutuskan tindakan apa yang akan diambil dan mempertimbangkan semua informasi yang tersedia. TRA menjelaskan bahwa perilaku tersebut disebabkan oleh minat atau keinginan individu untuk melakukannya. Selanjutnya menurut Ajzen (1980) menyatakan bahwa minat melakukan atau tidak melakukan perilaku tertentu dipengaruhi oleh dua penentu dasar, yaitu yang pertama berhubungan dengan sikap (attitude towards behavior) dan yang lain berhubungan dengan pengaruh sosial yaitu norma subjektif (subjective norms).

\section{Mobile Banking}

Mobile banking (M-banking) adalah layanan perbankan yang dirancang untuk membantu nasabah melakukan transaksi keuangan tanpa harus pergi ke bank atau ATM kecuali untuk penarikan (Wibiadila, 2016). Suroso (2018) menjelaskan bahwa sebuah strategi bagi layanan digital $m$-banking pada sebuah paradigma yang dihasilkan yang nantinya akan memunculkan sebuah masalah baru. Peluncuran M-banking merupakan layanan maintenance yang memanfaatkan teknologi digital, yang sangat bermanfaat bagi masyarakat, terutama di era modern yang semuanya sudah menggunakan teknologi. Layanan mobile banking ini berbasis transaksi keuangan yang dikemas dalam bentuk aplikasi dan dapat diunduh melalui smartphone nasabah. Orang yang berpikir bahwa menggunakan sistem memudahkan pekerjaan mereka akan tertarik untuk menggunakan sistem dan menggunakannya secara berkelanjutan (Ni Wayan Dewi Mas Yogi Pertiwi, 2017).

\section{Konsep Pengetahuan Produk/Layanan Secara Umum}

Informasi yang disampaikan oleh bank meliputi nama produk, jenis produk, cara produk digunakan, produk yang diterbitkan, dan biaya produk yang dikeluarkan. Informasi yang dikeluarkan berupa sebuah data yang dilakukan oleh customer service dengan prosedur yang sudah disampaikan dan dibagikan kepada nasabah.

\section{Faktor-faktor yang Mempengaruhi Pengetahuan}

Adapun beberapa faktor yang mempengaruhi pengetahuan nasabah menurut Alba dan Huchinsondi (1987) menyatakan: 
1. Subjective knowledge, pengetahuan yang didasarkan pada sebuah layanan produk.

2. Objective knowledge, sebuah pengetahuan yang disimpan pada sebuah memori akrual.

3. Experience-based, produk yang digunakan dengan memiliki sebuah pengalaman.

\section{Perceived Usefulness (PU)}

Davis (1989) menjelaskan bahwa kepercayaan yang dimiliki oleh individu akan memberikan peningkatan pada pekerjaannta dengan menggunakan sebuah teknologi yang digunakan.

Berdasarkan penelitian sebelumnya yang dilakukan oleh Ratmatsyah (2011), Anendro (2016) pada penelitiannya persepsi kegunaan (PU) menunjukan pengaruh pada kartu FLAZZ BCA pada emoney. Anendro (2016), menunjukan bahwa persepsi kegunaan (PU) tidak berpengaruh signifikan terhadap minat nasabah Bank Mandiri Syariah dalam menggunakan mobile banking. Berdasarkan penelitian yang dilakukan oleh Aritonang (2017) menunjukan bahwa persepsi kegunaan (PU) berpengaruh signifikan terhadap minat customer dalam menggunakan e-money Go-Pay.

\section{Perceived Ease of Use (PEOU)}

Davis (1989) menjelaskan bahwa kepercayaan yang dimiliki oleh individu akan memberikan peningkatan pada pekerjaannta dengan menggunakan sebuah teknologi yang digunakan. Pengguna sistem dengan perkembangan sistem baru dalam mengop[erasikan sebuah sistem yang digunakan sesuai dengan keiinginan yang di gunakan. Hal ini menunjukan dengan adanya sebuah intensitas pada sebuah sistem memberikan sebuah operasi yang dilakukan oleh pengguna tersebut.

Rahmatsyah (2011), dalam penelitiannnya menjelaskan bahwa terdapat sebuah hubungan antara persepsi kemudahan dengan minat nasabah yang memiliki hasil yang signifikan pada kartu FLAZZ BCA pada pemakaian e-money. Anendro (2016) pengaruh signifikan antara minat bank Mandiri Syariah terhadap persepis dengan mobile banking. Aritonang (2017) menunjukan bahwa persepsi kemudahan dalam penggunaan (PEOU) berpengaruh signifikan terhadap minat customer dalam menggunakan emoney Go-Pay.

\section{E-Money}

E-money dapat diartikan sebagai suatu produk berupa alat pembayaran berbentuk data digital yang dimana sejumlah nilai uang disimpan dalam sebuah media elektronik yang dimiliki oleh seseorang pada media penyimpanan yang beragam. Uang elektronik ini atau yang disebut e-money juga memiliki keunggulan dimana para pengguna e-money tidak perlu membawa uang dalam bentuk fisik untuk membayar dan sifatnya yang praktis sangat memudahkan dalam penggunaannya, disisi lainnya e-money juga memiliki adanya kelemahan, dimana karena nominal yang tersimpan didalam media penyimpanan digital maka sudah pasti akan terjaddi kerusakan dalam server (server down) atau error saat ingin mengisi saldo maupun membayar. Kelemahan ini akna dapat berpengaruh pada nominal yang dimiliki dan tidak semua transaksi bisa dilakukan dengan pembayaran e-money masih terbatas lingkupnya dalam guna membayar (Malhotra, 2012).

\section{TAM: Persepsi kemudahan penggunaan dan Persepsi manfaat kegunaan}

Davis et al (1989) memberikan pengertian TAM merupakan sebuah keyakinan sikap yang diberikan sebagaia penentu yang dijadikan pada sebuah sistem informasi yang telah disediakan. Misalnya, menggunakan uang elektronik sebagai pengganti mata uang sebagai alat pembayaran dalam berbelanja, jika mudah digunakan dan mudah dipelajari penggunaannya, akan dianggap mudah digunakan. Davis dkk. (1989) mendefinisikan bahwa jika penggunaan sistem dapat meningkatkan kinerja, konsumen akan mempertimbangkan kegunaan sistem tersebut. Misalnya, konsumen akan melihat manfaat menggunakan uang elektronik karena memungkinkan mereka memproses pembayaran lebih cepat dan lebih nyaman daripada uang atau pembayaran elektronik lainnya.

Hasil penelitian yang dilakukan oleh Agustina dan Arief (2015) menunjukkan bahwa variabel persepsi kemudahan tidak berpengaruh signifikan terhadap internet banking. Semakin tinggi persepsi 
kemudahan mengindikasikan bahwa semakin mudah M-Banking Mandiri digunakan, sehingga pengguna akan semakin sering menggunakan dan berdampak pada peningkatan sikap positif dalam penggunaan M-banking. Maka dengan demikian dapat dikatakan persepsi kemudahan penggunaan (PEOU) berpengaruh positif terhadap Sikap (A) pengguna M-Banking.

Dua persepsi yang dijadikan sebuah dasar yang dipakai dalam persepsi kemudahan dan kegunaan dalam teknologi yang digunakan oleh individu. Alat bantu serta efisiensi untuk diri sendiri merupakan sebuah cara yang digunakan sebagai pengaruh dalam melakukan sebuah perubahan (Davis et al., 1989). Apabila terdapat sebuah kesulitan dalam melakukan sebuah proses pembayaran maka akan terjadi sebuah alternatif pada pembayaran yang dilakukan secara langsung. TAM ini akan berpengaruh dengan keyakinan pada hipotesis berikut ini. Hasil penelitian yang dilakukan oleh Agustina dan Arief (2015) menunjukkan bahwa persepsi manfaat berpengaruh secara positif dan signifikan terhadap sikap penggunaan internet banking.

Semakin tinggi persepsi manfaat maka mengindikasikan bahwa menurut responden, manfaat yang diterimanya dalam menggunakan M-banking Mandiri akan semakin baik sehingga akan meningkatkan sikap positif pengguna M-banking. Dengan demikian dapat dikatakan bahwa Persepsi manfaat (PU) berpengaruh positif terhadap Sikap (A) pengguna M-banking.

Alat bantu yang digunakan pada sebuah persepsi yang dipakai yaitu kemudahan dan kegunaan dengan perubahan yang memiliki sebuah pengaruh dalam membantu untuk memberikan sebuah efisiensi waktu bagi nasabah (Davis, 1989; Davis et al 1989.). Layanan M-banking memberikan sebuah focus pada manfaat yang bisa dinikmati pada penggunaan M-banking. Manfaat kegunaan dengan minat memiliki sebuah pengaruh langsung dengan hasil yang dilakukan pada informasi yang terdapat di $M$ banking. Hamid (2016) menjelaskan bahwa adanya pengaruh yang baik antara persepsi manfaat dengan kemudahan dalam menggunakan sebuah teknologi informasi yang diperlukan.

Semakin tinggi persepsi kemudahan pengguna mengindikasikan bahwa pengguna M-banking semakin mudah dalam menggunakan $M$-Bankingnya sehingga akan meningkatkan persepsi manfaat $M$ Banking. Dengan demikian dapat dikatakan bahwa Persepsi kemudahan penggunaan (PEOU) berpengaruh positif terhadap persepsi manfaat (PU).

Davis et al (1989) menjelaskan bahwa untuk meningkatkan kinerja karyawannya, seseorang percaya terdapat sebuah kegunaan yang dapat dirasakan serta percaya dengan hasil yang telah dikerjakannya. Alat bantu yang digunakan pada sebuah persepsi yang dipakai yaitu kemudahan dan kegunaan dengan perubahan yang memiliki sebuah pengaruh dalam membantu untuk memberikan sebuah efisiensi waktu bagi nasabah (Davis, 1989; Davis et al 1989). Utami dan Kusumawati (2017) ; Husni dan Fairol (2016) memberikan sebuah manfaat dengan hubungan yang negatif pada sebuah dampak aktual yang diberikan pada sebuah persepsi manfaat.

Semakin tinggi persepsi manfaat yang diterima oleh seorang pengguna M-Banking mengindikasikan bahwa manfaat makin besar sehingga akan semakin tinggi minat dalam menggunakan M-Banking. Dengan demikian dapat dikatakan bahwa Persepsi manfaat (PU) berpengaruh positif terhadap minat menggunakan (ITU) M-Banking. Hipotesis disusun sebagai berikut:

$\mathrm{H} 1$ : $\quad$ Persepsi kemudahan penggunaan (PEOU) berpengaruh positif terhadap Sikap (A) pengguna $M$ Banking.

$\mathrm{H} 2$ : $\quad$ Persepsi manfaat (PU) berpengaruh positif terhadap Sikap (A) pengguna M-Banking.

H3: $\quad$ Persepsi kemudahan penggunaan (PEOU) berpengaruh positif terhadap persepsi manfaat (PU) M-Banking.

H4: $\quad$ Persepsi manfaat (PU) berpengaruh positif terhadap minat menggunakan (ITU) M-Banking. 


\section{TPB keyakinan Normatif : Norma Subyektif}

Norma subyektif merupakan sebuah hubungan yang saling memliki keyakinan dengan pemenuhan sebuah tindakan dan keyakinan pada seseorang dalam melakukan sesuatu (Davis et al, 1989;, Fishbein dan Ajzen, 1975).

Apabila normal subjektif semakin baik mengindikasikan bahwa seseorang dalam menggunakan M-Banking semakin baik sehingga akan meningkatkan persepsi manfaat atau PU M-Banking. Dengan demikian dapat dikatakan bahwa Norma Subyektif (SN) berpengaruh positif terhadap persepsi manfaat (PU) M-Banking.

Pengalaman yang tidak terllau banyak dengan pengaruh yang dikelompokan oleh anggota keluarga yang dipengaruhi ada rekan kerja yang dilakukan. Oleh karena itu, penelitian ini mengandaikan bahwa norma subyektif positif akan memengaruhi kesediaan nasabah untuk berpartisipasi dalam melakukan transaksi menggunakan M-Banking pada saat melakukan pembayaran. Hasil penelitian yang dilakukan oleh Rahmatika dan Fajar (2019) menunjukkan bahwa norma subjektif mempengaruhi minat penggunaan e-money. Artinya semakin tinggi norma subjektif maka akan meningkatkan minat menggunakan M-banking.

Apabila semakin tinggi norma subjektif (NS) pada sebuah perbankan berarti responden atau pengguna M-Banking akan memiliki norma yang baik sehingga meningkatkan minat menggunakan $M$ Banking. Dengan demikian dapat dikatakan bahwa Norma Subyektif (NS) berpengaruh positif terhadap minat menggunakan (ITU) M-Banking. Hipotesis disusun sebagai berikut:

H5: $\quad$ Norma Subyektif (SN) berpengaruh positif terhadap persepsi manfaat (PU) M-Banking.

H6: $\quad$ Norma Subyektif (NS) berpengaruh positif terhadap minat menggunakan (ITU) M-Banking.

\section{Sikap dan Minat}

Minat perilaku yang digunakan pada model TAM dan TPB dengan menggunakan persepsi kepercayaan. Davis et al (1989) memberikan sebuah kompoen kognitif dengan menggunkan sebuah komponen emosional. Kepercayaan antara minta perilaku memberikan sebuah mediator yang menjadi sikap (Bajaj dan Nidumolo, 1998). Artinya semakin tinggi sikap maka semakin tertarik pengguna mobile banking. Hipotesis disusun sebagai berikut:

H7 : $\quad$ Sikap (A) berpengaruh positif terhadap minat menggunakan (ITU) M-Banking

\section{METODE PENELITIAN}

Kuantitatif deskriptif merupakan sebuah metode yang digunakan pada penelitian ini. Metode ini didasarkan pada metode dengan pengujian sebuah hipotesis dengan pemanfaatkan yang digunakan. Jenis yang digunakan pada penelitian ini dengan menggunakan google form yang akan diisikan langsung oleh responden. Penelitian ini memberikan sebuah respon dengan layanan M-banking yang telah digunakan. Teknik yang digunakan dengan purposive sampling dengan populasi yang ditentukan (Jogiyanto, 2013). Survey yang digunakan pada data yang dikumpulkan. Survey merupakan sebuah pertanyaan yang diberikan kepada responden yang disebut data primer (Jogiyanto, 2013).

Populasi dalam penelitian ini adalah seluruh pengguna M-Banking di Kota Yogyakarta. Maka populasinya adalah seluruh pengguna M-Banking di Kota Yogyakarta yang sudah bekerja.

\section{Tabel 1. Kriteria Sampel}

\begin{tabular}{|c|l|c|}
\hline No & \multicolumn{1}{|c|}{ Keterangan } & Jumlah \\
\hline 1 & Nasabah pengguna layanan M-Banking Mandiri. Sumber: BPS & 269 \\
\hline 2 & $\begin{array}{l}\text { Nasabah Bank Mandiri yang menggunakan M-banking tetapi sudah tidak aktif menggunakan dlm 3 } \\
\text { bulan terakhir. }\end{array}$ & $(48)$ \\
\hline 3 & Mereka yang berusia <18 tahun & $(45)$ \\
\hline & Total & 166 \\
\hline
\end{tabular}

Sumber: Data diolah, 2021 
Jumlah sampel yang digunakan pada penenelitian ini adalah 145 responden yang memiliki dan menjalankan M-banking di Yogyakarta, dengan menjawab pertanyaan kuesioner yang telah diberikan kepada responden (Malhotra, 2012).

\section{Variabel dan Pengukuran Variabel}

Tabel 2. Konstruk Item

\begin{tabular}{|c|c|c|}
\hline Variabel Laten & Indikator & Sumber \\
\hline $\begin{array}{l}\text { Perceived } \\
\text { Usefulness (PU) }\end{array}$ & $\begin{array}{l}\text { PU1 = mempercepat proses pembayaran } \\
\text { PU2 = meningkatkan ketelitian proses pembayaran } \\
\text { PU3 = merasa lebih aman } \\
\text { PU4 = memberikan promosi menarik } \\
\text { PU5 = lebih efisien }\end{array}$ & $\begin{array}{l}\text { Taylor and Todd (1995c); Mafe } \\
\text { etal (2009); Rigopoulos dan } \\
\text { Askounis (2007) }\end{array}$ \\
\hline $\begin{array}{l}\text { Perceived Ease of } \\
\text { Use (PEOU) }\end{array}$ & $\begin{array}{l}\text { PEOU1 = kemudahan untuk digunakan } \\
\text { PEOU2 = kemudahan untuk dipahami } \\
\text { PEOU3 = praktis dalam penggunaan } \\
\text { PEOU4 = fleksibilitas }\end{array}$ & $\begin{array}{l}\text { Rigopoulos dan Askounis } \\
\text { (2007); Davis (1989) }\end{array}$ \\
\hline $\begin{array}{l}\text { Subjective Norm } \\
\text { (SN) }\end{array}$ & $\begin{array}{l}\text { SN1 = keluarga mempengaruhi perilaku penggunaan } \\
\text { SN2 = rekan mempengaruhi perilaku penggunaan } \\
\text { SN3 = lingkungan social mempengaruhi perilaku } \\
\text { penggunaan }\end{array}$ & $\begin{array}{l}\text { Taylor and Todd (1995c);Peslak, } \\
\text { A., Ceccucci, W.\& Sendall, P. } \\
\text { (2010); Shih, Y. and Fang, K. } \\
\text { (2004) }\end{array}$ \\
\hline Attitude (A) & $\begin{array}{l}\mathrm{A} 1=\text { diinginkan } \\
\mathrm{A} 2=\text { berguna } \\
\mathrm{A} 3=\text { baik } \\
\mathrm{A} 4=\text { menyenangkan }\end{array}$ & $\begin{array}{l}\text { Taylor and Todd (1995c); } \\
\text { Bhattacherjee, A (2000); Peslak, } \\
\text { A., Ceccucci, W.\& Sendall, P. } \\
\text { (2010) }\end{array}$ \\
\hline $\begin{array}{l}\text { Intention to Use } \\
\text { (ITU) }\end{array}$ & $\begin{array}{l}\text { ITU } 1 \text { = berniatmenggunakan } \\
\text { ITU } 2 \text { = mencoba menggunakan } \\
\text { ITU } 3 \text { = berencana menggunakan }\end{array}$ & $\begin{array}{l}\text { Taylor and Todd (1995c); } \\
\text { Sigopoulos and Askounis } \\
\text { (2007); Peslak, A., Ceccucci, } \\
\text { W.\& Sendall, P. (2010) }\end{array}$ \\
\hline
\end{tabular}

Sumber: Berbagai jurnal

\section{Alat Analisis Data} Uji Validitas

Validitas tes mengacu pada sejauh mana tes benar-benar mengukur apa yang diklaim untuk diukur. Validitas tes juga merupakan sejauh mana kesimpulan, kesimpulan, dan keputusan yang dibuat berdasarkan nilai tes adalah tepat dan bermakna.

\section{Uji Reliabilitas}

Keandalan tes mengacu pada sejauh mana tes konsisten dan stabil dalam mengukur apa yang ingin diukur. Sederhananya, sebuah tes dapat diandalkan jika konsisten dalam dirinya sendiri dan sepanjang waktu (Ghozali, 2011).

\section{Metode Analisis}

SEM AMOS

Sugiyono (2016) SEM dengan mengembangkan sebuah 2 komponen yaitu model pengukuran dan model struktural. Istilah tersebut terkait dengan pengukuean eksogen dan endogen dengan hasil sebuah hasil pada penelitian. Sedangkan model pengukuran adalah model yang merupakan bagian dari Model SEM yang biasanya dikaitkan dengan variabel laten dan indikator. Hubungan dalam model ini dilakukan melalui faktor konfirmatori model analisis atau analisis faktor konfirmatori (CFA) di mana kovariat antara setiap pasangan variabel dimungkinkan.

RMSEA adalah pengukuran perkiraan kecocokan dalam populasi dan karena itu prihatin dengan perbedaan karena pendekatan. RMSEA diperkirakan dengan akar kuadrat dari perkiraan perbedaan karena pendekatan per derajat kebebasan. RMSEA dianggap sebagai: relatif tidak tergantung pada ukuran sampel, dan lebih disukai model pelit. Menurut Browne \& Cudeck (dikutip dalam Ghozali \& Fuad, 2008), menyatakan bahwa RMSEA mampu mengkuantifikasi nilai parameter deviasi dalam model dengan matriks kovarians dari populasi. Standar dari RMSEA sebagai berikut: 
1. Jika RMSEA 0,5 menunjukkan model fit (Byrne, 1998).

2. Jika RMSEA = $0.8-1.0$, maka model tersebut memiliki kecocokan yaitu sedang (cukup).

3. Jika RMSEA 1, ini menunjukkan model fit yang buruk.

AGFI adalah untuk menyesuaikan bias sebagai akibat dari model kompleksitas. AGFI menyesuaikan model derajat kebebasan relative dengan jumlah variabel yang diamati dan karena itu memberikan penghargaan yang lebih sedikit model kompleks dengan parameter yang lebih sedikit. AGFI mendekati GFI. Aturan untuk indeks ini adalah 0,90 akan menjadi indikator kesesuaian relatif terhadap model dasar, sedangkan nilai yang lebih besar dari 0,85 dapat dianggap sebagai kecocokan yang dapat diterima (dikutip dalam Ghozali \& Fuad, 2008).

Nilai CFI berkisar dari 0 hingga 1 . Jika nilai $\mathrm{CFI}$ adalah 0,90 , itu menunjukkan kesesuaian yang baik. Sedangkan jika nilai CFI berada di antara $0.80 \mathrm{CFI} 0.90$, sering disebut sebagai marginal fit (Kasanah, 2015). Bentler (dikutip dalam Ghozali \& Fuad, 2008) menyatakan bahwa CFI sangat direkomendasikan sebagai alat untuk mengukur kecocokan model.

$\mathrm{NFI}$ adalah perbandingan antara model yang diusulkan dan model nol. Jika nilai NFI >0,90, model tersebut dianggap sebagai model yang baik.

\section{HASIL DAN PEMBAHASAN}

\section{Hasil Uji Validitas Dan Reliabilitas}

Berdasarkan hasil pengujian hasil diperoleh bahwa nilai $r$ hitung PU1 0.751, PU2 0.772, PU3 0.857, PU4 0.753, dan PU5 0.836 dengan nilai lebih dari 0.138 maka hasil yang diperoleh > r table maka keterangannya adalah valid.

Tabel 3. Uji Validitas Variabel Perceived Usefulness (PU)

\begin{tabular}{|l|c|c|c|}
\hline No. Item pertanyaan & $r$ hitung & $r$ table & Keterangan \\
\hline PU1 & 0.751 & 0.138 & Valid \\
\hline PU2 & 0.772 & 0.138 & Valid \\
\hline PU3 & 0.857 & 0.138 & Valid \\
\hline PU4 & 0.753 & 0.138 & Valid \\
\hline PU5 & 0.836 & 0.138 & Valid \\
\hline
\end{tabular}

Sumber : Data yang diolah (2021)

Berdasarkan hasil pengujian hasil diperoleh bahwa nilai $r$ hitung PEOU1 0.905, PEOU2 0.909, PEOU3 0.911, dan PEOU4 0.891 dengan nilai lebih dari 0.138 maka hasil yang diperoleh $>r$ table maka keterangannya adalah valid.

Tabel 4. Uji Validitas Variabel Perceived Ease of Use (PEOU)

\begin{tabular}{|l|c|c|c|}
\hline No. Item pertanyaan & $r$ hitung & $r$ table & Keterangan \\
\hline PEOU1 & 0.905 & 0.138 & Valid \\
\hline PEOU2 & 0.909 & 0.138 & Valid \\
\hline PEOU3 & 0.911 & 0.138 & Valid \\
\hline PEOU4 & 0.891 & 0.138 & Valid \\
\hline
\end{tabular}

Sumber : Data yang diolah (2021) 
Tabel 5. Uji Validitas Variabel Subjective Norm (SN)

\begin{tabular}{|l|c|c|c|}
\hline No. Item pertanyaan & $r$ hitung & $r$ table & Keterangan \\
\hline SN1 & 0.834 & 0.138 & Valid \\
\hline SN2 & 0.844 & 0.138 & Valid \\
\hline SN3 & 0.826 & 0.138 & Valid \\
\hline
\end{tabular}

Sumber : Data yang diolah (2021)

Berdasarkan hasil pengujian hasil diperoleh bahwa nilai r hitung SN1 0.834, SN2 0.844, dan SN3 0.826 , dengan nilai lebih dari 0.138 maka hasil yang diperoleh $>r$ table maka keterangannya adalah valid.

Tabel 6. Uji Validitas Variabel Attitude (A)

\begin{tabular}{|c|c|c|c|}
\hline $\begin{array}{c}\text { No. Item } \\
\text { pertanyaan }\end{array}$ & r hitung & $r$ table & Keterangan \\
\hline A1 & 0.856 & 0.138 & Valid \\
\hline A2 & 0.883 & 0.138 & Valid \\
\hline A3 & 0.873 & 0.138 & Valid \\
\hline A4 & 0.951 & 0.138 & Valid \\
\hline
\end{tabular}

Sumber : Data yang diolah (2021)

Berdasarkan hasil pengujian hasil diperoleh bahwa nilai $r$ hitung $A 10.856, A 20.883, A 30.873$, dan A4 0.951 dengan nilai lebih dari 0.138 maka hasil yang diperoleh > r table maka keterangannya adalah valid.

Tabel 7. Uji Validitas Variabel Intention to Use (ITU)

\begin{tabular}{|l|c|c|c|}
\hline No. Item pertanyaan & $r$ hitung & $r$ tabel & Keterangan \\
\hline ITU1 & 0.947 & 0.138 & Valid \\
\hline ITU2 & 0.962 & 0.138 & Valid \\
\hline ITU3 & 0.909 & 0.138 & Valid \\
\hline
\end{tabular}

Sumber : Data yang diolah (2021)

Berdasarkan hasil pengujian hasil diperoleh bahwa nilai $r$ hitung ITU1 0.947, ITU2 0.962, dan ITU3 0.909 dengan nilai lebih dari 0.138 dengan nilai lebih dari 0.138 maka hasil yang diperoleh $>r$ table maka keterangannya adalah valid.

Tabel 8. Hasil Uji Reliabilitas

\begin{tabular}{|l|c|c|}
\hline \multicolumn{1}{|c|}{ Variabel } & Alpha Cronbach & Keterangan \\
\hline Perceived Usefulness (PU) & 0.918 & Reliabel \\
\hline $\begin{array}{l}\text { Perceived Ease of Use } \\
\text { (PEOU) }\end{array}$ & 0.961 & Reliabel \\
\hline Subjective Norm (SN) & 0.917 & Reliabel \\
\hline Attitude (A) & 0.955 & Reliabel \\
\hline Intention to Use (ITU) & 0.972 & Reliabel \\
\hline
\end{tabular}

Sumber : Data yang diolah (2021)

Hasil perceived usefulness dengan hasil 0.918, perceiver ease of use dengan hasil 0.961 , subjective norm dengan hasil 0.917 , attitude dengan hasil 0.955 , dan intention to use dengan hasil 0.972 , maka hasil uji reabilitasnya adalah reliabilititas. 


\section{Pengujian Hipotesis Penelitian}

Hasil Analisis AMOS

Analisis Structural Equation Modeling

Tabel 9. Goodness of Fit Indeks untuk Full Model

\begin{tabular}{|c|c|c|c|}
\hline $\begin{array}{c}\text { Goodness ofFit } \\
\text { Indeks }\end{array}$ & Kriteria & $\begin{array}{c}\text { Hasil } \\
\text { Analisis }\end{array}$ & $\begin{array}{c}\text { Evaluasi } \\
\text { Model }\end{array}$ \\
\hline AGFI & $\geq 0.90$ & 0,985 & Baik \\
GFI & $\geq 0.90$ & 0,961 & Baik \\
NFI & $\geq 0.90$ & 0,986 & Baik \\
CFI & $\geq 0.90$ & 0,910 & Baik \\
CMIN/DF & $\leq 3.00$ & 1,284 & Baik \\
RMSEA & $\leq 0.70$ & 0,126 & Baik \\
\hline
\end{tabular}

Sumber : Data yang diolah (2021)

Analisis SEM pada penelitian ini adalah:

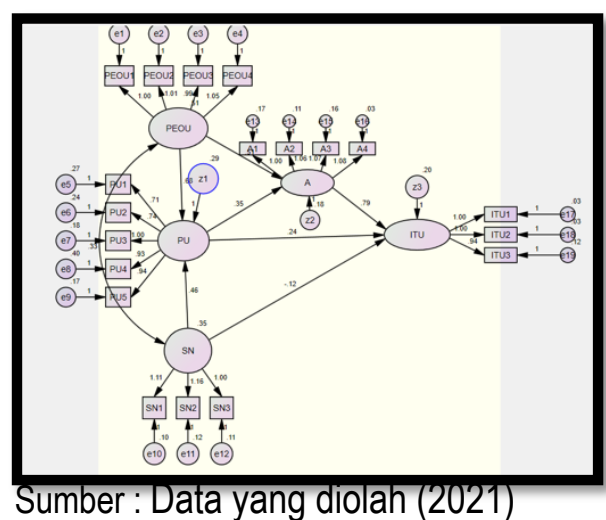

Gambar 1. Analisis SEM

Berikut ini merupakan hasil analisis hipotesis AMOS yag ada pada penelitian berikut ini:

Tabel 10.

Estimasi Parameter Regression Weights

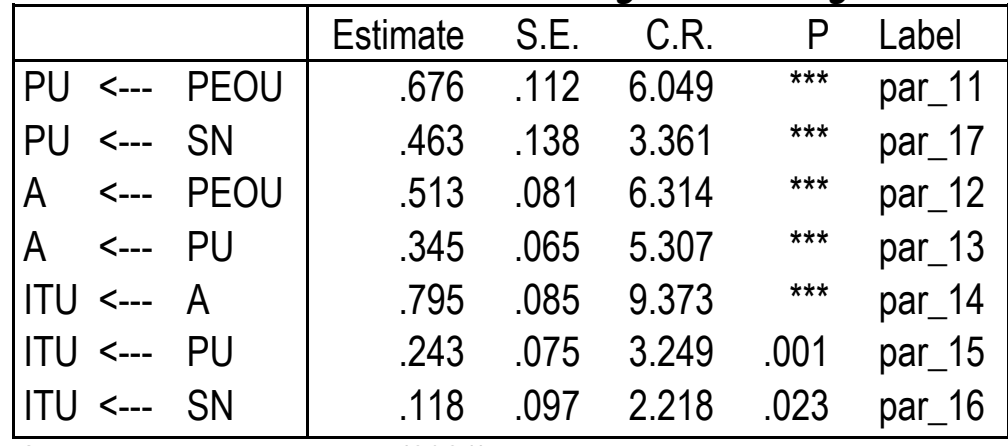

Sumber : Data yang diolah (2021)

Uji Hipotesis 1: Persepsi kemudahan penggunaan (PEOU) berpengaruh positif terhadap Sikap Sikap (A) pengguna M-Banking (A) pengguna M-Banking.

Uji Hipotesis 2: Persepsi manfaat (PU) berpengaruh positif terhadap Sikap (A) pengguna M-Banking.

Uji Hipotesis 3: Persepsi kemudahan penggunaan (PEOU) berpengaruh positif terhadap persepsi manfaat (PU) M-Banking.

Uji Hipotesis 4 : Persepsi manfaat (PU) berpengaruh positif terhadap minat menggunakan (ITU) MBanking. 
Uji Hipotesis 5: Norma Subyektif (SN) berpengaruh positif terhadap persepsi manfaat (PU) MBanking.

Uji Hipotesis 6: Norma Subyektif (SN) berpengaruh positif terhadap minat menggunakan (ITU) MBanking.

Uji Hipotesis 7 : Sikap (A) berpengaruh positif terhadap minat menggunakan (ITU) M-Banking.

Pembahasan Hasil Penelitian

Berdasarkan hasil pengolahan data bahwa nilai variabel Persepsi kemudahan penggunaan (PEOU) terhadap Sikap (A) pengguna M-Banking seperti terlihat pada tabel 10 adalah sebesar 6,314 dengan nilai $P$ (Probability) sebesar 0.000 . Kedua nilai ini menunjukkan hasil yang memenuhi syarat, karena diatas 2.00 untuk CR (Critical Ratio) dan dibawah 0.05 untuk nilai P (Probability). Dengan demikian dapat dikatakan bahwa hipotesis 1 penelitian ini diterima. Hipotesis ke-2 pengaruh antara variabel Persepsi manfaat (PU) terhadap Sikap (A) seperti terlihat pada tabel 10 adalah sebesar 5.307 dengan nilai $P$ (Probability) sebesar 0.000 . Dengan demikian dapat dikatakan bahwa hipotesis 2 penelitian ini dapat diterima. Hipotesis ke - 3 pengaruh antara variabel Persepsi kemudahan penggunaan (PEOU) terhadap persepsi manfaat (PU) seperti terlihat pada tabel 10 sebesar 6.049 dengan nilai $P$ (Probability) sebesar 0.000 . Dengan demikian dapat dikatakan bahwa hipotesis 3 penelitian ini dapat diterima. Hipotesis ke - 4 CR (Critical Ratio) untuk pengaruh antara variabel Persepsi manfaat (PU) terhadap minat menggunakan (ITU) seperti terlihat pada tabel 10 adalah sebesar 3.249 dengan nilai $P$ (Probability) sebesar 0.001. Dengan demikian dapat dikatakan bahwa hipotesis 4 penelitian ini dapat diterima. Hipotesis ke - 5 nilai CR (Critical Ratio) untuk pengaruh antara variabel Norma Subyektif (SN) terhadap persepsi manfaat (PU) M-Banking seperti terlihat pada tabel 10 adalah sebesar 3.361 dengan nilai P (Probability) sebesar 0.000. Dengan demikian dapat dikatakan bahwa hipotesis 5 penelitian ini diterima. Hipotesis ke - 6 nilai CR (Critical Ratio) untuk pengaruh antara variabel Norma Subyektif (SN) terhadap minat menggunakan (ITU) M-Banking seperti terlihat pada tabel 10 adalah sebesar 2.218 dengan nilai $P$ (Probability) sebesar 0.023. Dengan demikian dapat dikatakan bahwa hipotesis 6 penelitian ini diterima.

\section{PENUTUP \\ Kesimpulan}

Berdasarkan hasil analisis dan pengujian data, maka diperoleh kesimpulan sebagai berikut: Persepsi kemudahan penggunaan (PEOU) berpengaruh positif terhadap Sikap (A) pengguna M-Banking, Norma Subyektif (NS) berpengaruh positif terhadap minat menggunakan (ITU) M-Banking, Persepsi kemudahan penggunaan (PEOU) berpengaruh positif terhadap persepsi manfaat (PU) M-Banking, Persepsi manfaat (PU) berpengaruh positif terhadap minat menggunakan (ITU) M-Banking, Norma Subyektif (SN) berpengaruh positif terhadap persepsi manfaat (PU) M-Banking, Norma Subyektif (NS) berpengaruh positif terhadap minat menggunakan (ITU) M-Banking, Sikap (A) berpengaruh positif terhadap minat menggunakan (ITU) M-Banking.

Dilihat dari nilai statistik deskriptifnya mean untuk variabel PU sebesar 4.2234 artinya masuk dalam kategori tinggi atau setuju, sedangkan untuk PEOU nilai mean sebesar 3.8768, untuk variabel SN nilai mean sebesar 3.4118 dan untuk variabel S 3.4130 dan variabel ITU sebesar 3.4493 yang artinya masuk kategori sedang. Jadi sebaiknya dapat mempertahankan Persepsi kemudahan penggunaan, meningkatkan Persepsi manfaat, norma subjektif karena berdasarkan pada hasil penelitian ini terbukti signifikan berpengaruh terhadap penggunaan M-Banking. 


\section{Saran}

Saran pada penelitian ini yaitu:

1. Sebaiknya pihak perbankan dapat meningkatkan Persepsi kemudahan penggunaan, Persepsi manfaat, norma subjektif karena berdasarkan pada penggunaan M-Banking.

2. Variabel yang berpengaruh dengan topic yang akan dating dengan pengaruh penggunaan $M$-Banking atau menambahkan variabel moderating.

\section{DAFTAR PUSTAKA:}

Agustina, Usfatul Ika dan Mohammad Arief. (2015). Pengaruh Persepsi Manfaat dan Persepsi Kemudahan terhadap Sikap Penggunaan Layanan Internet Banking (Study Pada Komunitas Virtual E-Banking BCA). Jurnal Ekonomi Bisnis Tahun 20, Nomor 2, Juli 2015, hlm 53-138.

Alba, Joseph W \& Hutchinson, J Wesley. (1987). Dimensions of Consumer Expertise. Journal of Consumer Research, Vol 13. Pp 411-454.

Ajzen, I. \& Fishbein, M. (1980) Understanding Attitudes and Predicting Social Behavior Englewood Cliffs, $\mathrm{NJ}$ : Prentice-Hall.

Ajzen, I. (1991). The Theory of Planned Behavior. Organizational Behavior and Human Decision Processes, 50: 179-211.

Bateni. (2014). "The Influential Factors On Capital Adequacy Ratio In Iranian Banks". International Journal of Economics and Finance Vol 6 No 11. Pp 108-116.

Calantone, R. J., Griffith, D. A. \& Yalcinkaya, G., (2006). An Empirical Examination of a Technology Adoption for the Context of China. Journal of International Marketing, pp. 1-27.

Davis,F.D. (1989). "Perceived Usefulness, Perceived Ease of Use, and User Acceptance of Information Technology". MIS Quarterly.Vol. 13 No. 5: pp319-339.

Fadlan, Abi dan Rizki Yudhi Dewantara. (2018). Pengaruh Persepsi Kemudahan Dan Persepsi Kegunaan Terhadap Penggunaan Mobile Banking (Studi Pada Mahasiswa Pengguna Mobile Banking Universitas Brawijaya). Jurnal Administrasi Bisnis (JAB). Vol. 62 No. 1 September 2018.

Fishbein, M, \& Ajzen, I. (1975). Belief, Attitude, Intention, and Behavior: An Introduction to Theory and Research, Reading, MA: Addison-Wesley.

Gatignon, H. \& Robertson, T. S., (1989). Technology Diffusion: An Empirical Test of Competitive Effects. Journal of Marketing, Issue 53, pp. 35-49.

Ghozali, Imam. (2011). "Aplikasi Analisis Multivariate Dengan Program SPSS". Semarang: Badan Penerbit Universitas Diponegoro.

Husni, K., \& Halim Fairol. (2016). The Intention to Use E-Money Transaction in Indonesia based on Tam and TPB Concept. Asia-Pacific Marketing Review, 3(1), 53-57.

Jogiyanto, (2007). Sistem Informasi Keprilakuan. Edisi Revisi penyunt. Yogyakarta: Andi Publisher.

Keat, K.T. \& Mohan, A. (2004). Integration Of TAM Based Electronic Commerce Models For Trust. The Journal Of American Academy Of Business. Cambridge.

Khaled. (2013). "Determinants Of Capital Adequacy In Commercial Banks Of Jordan An Empirical Study". International Journal of Academic Research in Economics and Management Sciences. Vol 2 No 4. Pp 44-58.

Malhotra, N.K. (2012). Basic Marketing Research : Integration of Social Media. Jakarta : PT Index Kelompok Gramedia.

Melasari, Cita, Suroso, Agus, Banani, Ade. (2018). Pengaruh Kepercayaan, Kegunaan, Kemudahan, Privacy Risk, Time Risk, dan Financial Risk terhadap Minat Penggunaan Mobile Banking Bank 
Muamalat. Performance: Jurnal Personalia, Financial, Operasional, Marketing dan Sistem Informasi, [S.I.], v. 25, n. 1, p. 11-23, jan. 2018. ISSN 2615-8094.

Pertiwi, Ni Wayan Dewi Mas Yogi dan Dodik Ariyanto. (2017). Penerapan Model UTAUT2 Untuk Menjelaskan Minat Dan Perilaku Penggunaan Mobile Banking Di Kota Denpasar. E-Jurnal Akuntansi Universitas Udayana. Vol.18. Hal : 1369-1397 ISSN: 2302-8556.

Ryan, Michael J. \& E. H. Bonfield (1980), "Fishbein's Intentions Model: A Test of External a nd Pragmatic Validity," Journal of Marketing, 44(Spring):82- 95.

Sheppard, B.H., Hartwick, J., dan Warshaw, P.R. (1988). The Theory of Reasoned Action: A MetaAnalysis of Past Research with Recommendations for Modifications and Future Research. The Journal of Consumer Research, Vol.15, No.3, Desember, pp.325-343.

Utami, S. S., \& Kusumawati, B. (2017). Faktor-Faktor Yang Memengaruhi Minat Penggunaan E-Money (Studi pada Mahasiswa STIE Ahmad Dahlan Jakarta ). Balance, XIV(2), 30-41.

Venkatesh, V., Morris, M.G., Davis, G.B., \& Davis, F.D. (2003).User acceptance of information technology: Toward a unified view. MIS Quarterly, Vol. 27 No. 3, pp. 425-478.

Wibiadila, Ikbar and , Dr. Noer Sasongko, SE, M.Si, Ak (2016) Pengaruh Kegunaan, Kemudahan, Risiko, dan Kualitas Layanan terhadap Minat Nasabah dalam Menggunakan Mobile Banking (Survei Pada Nasabah Bank Mandiri Kantor Cabang Solo). Skripsi thesis, Universitas Muhammadiyah Surakarta. 